\title{
Farklı Silajlık Mısır Çeşitlerinin Hamur Olum Döneminde Silaj ve Tane Özelliklerinin Belirlenmesi
}

\author{
Uğur BAŞARAN ${ }^{1} \quad$ Erdem GÜLÜMSER ${ }^{2} \quad$ Medine ÇOPUR DOĞRUSÖZ ${ }^{1}$ Hanife MUT \\ Ayşenur ŞAHIN ${ }^{1}$ \\ ${ }^{1}$ Bozok Üniversitesi, Ziraat Fakültesi, Tarla Bitkileri Bölümü, Yozgat. \\ ${ }^{2}$ Bilecik Şeyh Edebali Üniversitesi, Ziraat ve Doğa Bilimleri Fakültesi, Bilecik \\ $\triangle$ : ugur.basaran@bozok.edu.tr
}

Geliş (Received): 02.11.2017

Kabul (Accepted): 18.12.2017

\begin{abstract}
ÖZET: Bu araştırma, 9 silajlık mısır çeşidinin (Cadız, Colonia, SY Lucrosa, Truva, BC 682, OSSK 596, DS 0224, Arifiye ve Sakarya) bazı silaj ve tane özelliklerinin belirlenmesi amacıyla 2013 ve 2014 yıllarında yürütülmüştür. Silaj ve tane özellikleri bitkilerin hamur olum döneminde incelenmiştir. Bu dönemde alınan bitkiler $2 \mathrm{~cm}$ boyutunda parçacıklara ayrılmış ve 2'şer litrelik plastik kaplarda $25 \pm 2{ }^{\circ} \mathrm{C}$ sıcaklıkta 75 gün süre ile silolanmıştır. Daha sonra silaj örnekleri $60^{\circ} \mathrm{C}$ 'de sabit ağırlığa gelinceye kadar kurutulmuş ve ögütülerek analize hazır hale getirilmiştir. Tane özellikleri için hamur olum döneminde alınan koçanlar $60^{\circ} \mathrm{C}$ 'de kurutularak, harmanlanmış ve öğütülerek analizi yapılmıştır. Silaj örneklerinde kuru madde oranı, ham protein oranı, ADF, NDF, K, P, Ca ve Mg içerikleri, tanede ise ham protein kül oranı ile nişasta ve yağ içerikleri belirlenmiştir. Birleştirilmiş yıllara göre; silaj örneklerinde kuru madde, ADF ve NDF oranları sirasıyla \% 28.36 - 34.58, \% 31.30 - 37.47 ve \% 50.53 - 60.40, tanede ise nişasta, yağ ve kül oranı sırasıyla \% 60.88 - 68.71, \% 4.48 - 5.32 ve \% $2.10-2.51$ arasında değişmiştir. En yüksek ham protein oranı silajda \% 9.09 ile SY Lucrosa, tanede \% 11.36 ile Arifiye çeşidinde belirlenmiştir. Bununla birlikte, silaj ve tane özellikleri arasındaki korelasyon da incelenmiş ve silajın kimyasal özellikleri ile tanenin içeriği arasında değişen oranlarda ilişki olduğu tespit edilmiştir.
\end{abstract}

Anahtar kelimeler: Silaj, misır, tane, kuru madde, protein.

\section{Determination of Silage and Grain Traits of Different Silage Maize Cultivars During Dough Stage}

\begin{abstract}
This study was conducted to determine some silage and grain quality characteristics of 9 silage maize varieties (Cad1z, Colonia, SY Lucrosa, Truva, BC 682, OSSK 596, DS 0224, Arifiye ve Sakarya) during the 2013 and 2014 growing seasons. Silage and grain characteristics of the plants were determined during the dough stage. The plants were separated into $2 \mathrm{~cm}$ sized particles and ensiled in 2 liter plastic cups at $25 \pm 2{ }^{\circ} \mathrm{C}$ for 75 days. Then, these silage samples were dried at $60{ }^{\circ} \mathrm{C}$ until the constant weight and milled for analysis. Dry matter content, crude protein ratio, $\mathrm{ADF}, \mathrm{NDF}, \mathrm{K}, \mathrm{P}, \mathrm{Ca}$ and $\mathrm{Mg}$ contents in silage samples and also crude protein, ash, starch and oil contents in the grain were investigated. Dry matter content, ADF and NDF rates in silage samples were ranged between 28.3-34.58\%, 31.30-37.47 \% and 47.31-61.80\% respectively. The strach, oil and ash content in grain samples were ranged between $60.88-68.71 \%, 4.48-5.32 \%$ and $2.10-2.51 \%$. The highest crude protein was determined $9.09 \%$ (SY Lucrosa) in silage while it was determined $11.36 \%$ (Arifiye) in grain. In addittion, the correlation between silage and grain characteristics was also investigated and it was determined that the chemical properties of silage are related to the content of grain in varying proportions.
\end{abstract}

Key words: Silage, maize, grain, dry matter, protein

\section{GíRiș}

Hayvancılıkta yaşanan sorunların önemli bir kısmı besleme ile yakından ilişsilidir. İdeal bir beslemenin temel ilkesi gerekli yem rasyonlarının hayvanların büyüme ve gelişme dönemleri dikkate alınarak bütün bir yıl boyunca devam ettirilmesidir. Özellikle süt ineklerinin verimlerini laktasyon dönemleri boyunca belli bir seviyede tutmak yem rasyonunun yeşil ve sulu yemlerle hazırlanmasıyla mümkündür.

Hayvanların yeşil yem ihtiyaçlarını doğadan taze olarak karşılamaları, her bölgenin kendine özgü ekolojik şartlarına bağlı olarak değişmekte ve bazı bölgelerde yaz ve sonbahar döneminde de yeşil yem temininde sorunlar yaşanmaktadır. Dolayısıyla hayvanların kış ayları başta olmak üzere yılın değişik dönemlerinde oluşan suca zengin kaba yem ihtiyaçları ancak silaj yapımı sayesinde karşılanabilmektedir. Silaj teknolojisi sayesinde bitkilerin tazeliğini çok fazla kaybetmeyen saklanması mümkün olmaktadır (Alçiçek ve ark., 2011). Mısır tüm dünyada ve ülkemizde silaj yapımında en fazla kullanılan bitkidir. Mısır yüksek şeker içeriği sayesinde hiçbir koruyucu madde kullanımına gerek duyulmaksızın saklanabilen, birim alanda fazla hazmolunabilir besin madde kaynağı olan, zengin ve laktik asit fermantasyonu için gerekli olan suda eriyebilir karbonhidratlarca zengin olan bir bitkidir. Ayrica misır silajı, kaliteli, bol ve ucuz kaba yem sağlaması, daha rahat depolanabilmesi ve depolanırken de besin madde kayıplarının daha az olması gibi 
sebeplerden dolayı avantajlıdır (Yaylak ve Alçiçek, 2003).

Mısır silajının kalitesi üzerinde olum dönemi önemlidir. Nitekim silajda olum dönemi bitkinin kuru madde düzeyi, enerji içeriği ve sindirilebilirlik parametrelerinin bir göstergesidir. Mısır silajı için en önemli enerji kaynağı mısırın tane kısmıdır ve en yüksek enerji içeriğine hamur olum döneminde ulaşılmaktadır (Hill, 1993).
$\mathrm{Bu}$ çalışmada farklı mısır çeşitlerinin tanelerinin silaj kalitesi üzerine etkilerinin belirlenmesi amaciyla 2013 ve 2014 yıllarında iki yıl süreyle yürütülmüştür.

\section{MATERYAL ve YÖNTEM}

Çalışma 2013 ve 2014 yıllarında Yozgat ili merkezine bağlı Baltasarı köyü çiftçi arazisinde ana ürün olarak iki yıl süreyle yürütülmüştür. Araştırmada Tablo 1'de özellikleri verilen dokuz adet silajlık mısır çeşidi kullanılmıştır.

Tablo 1. Araştırmada kullanılan mısır çeșitlerine ait bazı bilgiler

\begin{tabular}{lllc}
\hline No & Çeşit adi & Çeşit sahibi & FAO olum grubu \\
\hline 1 & Cadız & Fito Tohumculuk Ticaret Ltd. Şti. & 700 \\
2 & Colonia & Agromar San. ve Tic. A.Ş. & 650 \\
3 & Sakarya & Sakarya Misır Araştırma Enstitütüsü & 700 \\
4 & SY Lucrosa & Sygenta Tohumculuk Ticaret Ltd. Şti. & 600 \\
5 & OSSK 596 & Tareks Tohumculuk Tic. A.Ş. & $550-600$ \\
6 & Arifiye & Sakarya Misır Araştırma Enstitütüsü & $650-700$ \\
7 & BC 678 & BC Institut & 600 \\
8 & DS 0224 & Agromar San. ve Tic. A.Ş. & 600 \\
9 & Truva & Limagrain Tohum Islah ve Üretim San. Tic. A.Ş & 700
\end{tabular}

Hamur olum döneminde hasat edilen bitki örnekleri Ham protein oranı bakımıdan çeşitler ve yıllar yaklaşık olarak $2 \mathrm{~cm}$ boyunda parçalandıktan sonra 3 tekerrürlü olarak 2 litrelik bidonlara sıkıștırılarak konulmuştur. Hazırlanan silajlar $25 \pm 2{ }^{\circ} \mathrm{C}$ sicaklıkta ve 75 gün süre ile muhafaza edilmiştir (Kaya ve Polat, 2010). 75 gün sonunda açılan kaplardan alınan silaj örnekleri $60{ }^{\circ} \mathrm{C}$ 'de etüvde sabit ağırlığa gelinceye kadar kurutulmuş ve $1 \mathrm{~mm}$ elek çapına sahip değirmende öğ̈̈ülerek analize hazır hale getirilmiştir. Tane özellikleri için ise hamur olum döneminde alınan koçanlar $60{ }^{\circ} \mathrm{C}$ 'de kurutularak harmanlanmış ve ögütülerek analize hazır hale getirilmiştir. Silajda ham protein, ADF, NDF, Potasyum (K), Kalsiyum (Ca), Fosfor (P) ve Magnezyum (M)g, tane de ise ham protein, nişasta, yağ, ham kül değerleri Near Infrared Reflectance Spectroscopy (NIRS) (Foss 6500) cihazı ile IC-0904FE paket programı kullanılarak belirlenmiştir. sialjın kuru madde analizi ise açılan silaj kaplarından alınan örnekler $105{ }^{\circ} \mathrm{C}$ 'de etüvde sabit ağırlığa gelinceye kadar kurutularak belirlenmiştir,

Elde edilen sonuçlar SPSS 16.0 istatistik paket programı kullanılarak Tesadüf Blokları Deneme Desenine göre analiz edilmiştir. İşlemler arasındaki farklılıklar Duncan çoklu karşılaştırma testi ile ortaya konulmuştur.

\section{BULGULAR ve TARTIŞMA}

Silajlık mısır çeşitlerinin silaj ve tanelerinde belirlenen kalite özellikleri Tablo 2'de verilmiştir. Silaj örneklerinin kuru maddesi (KM) üzerinde yılların ve çeşitlerin etkisi çok önemli $(\mathrm{p}<0.01)$ olmuştur. Birleştirilmiş yıllara göre silajın kuru madde oranı \% 28.36 (Colonia) - 34.58 (Cadız) arasında değişmiştir. İyi bir mısır silajında kuru madde oranının \% $30-35$ arasında olması gerektiği (Kılıç, 1986) dikkate alındığında, Colania ve OSSK 596 çeşitleri dışında tüm çeşitler bu değerlerin arasında olmuştur (Tablo 2). Mısır silajı için elde edilen KM değerleri, Deniz ve ark (2001)'nın belirlemiş oldukları bulgular (\% 26.49 37.37) ile uyumlu iken, Arslan ve ark (2016)'nın belirlemiş olduğu değerden \% 44.42 daha düşük olmuştur. arasındaki fark çok önemli $(\mathrm{p}<0.01)$ olmuştur. Buna göre en yüksek ham protein oranı SY Lucrosa (\% 9.09), en düşük ise istatistiksel olarak aynı grupta yer alan \% 6.92 ile BC 678, \% 7.15 ile Arifiye, \% 7.20 ile Colonia ve \% 7.34 ile Cadız çeşitlerinden elde edilmiştir (Tablo 2). Araştırma sonucunda belirlenen ham protein oranı, Arslan ve ark (2017)'nın belirlemiş olduğu değerden (\% 5.95) daha yüksek olmuştur. Farklıklar kullanılan çeşit ve uygulanan kültürel işlemlerden kaynaklanmış olabilir.

Süt sığırı rasyonlarında yüksek düzeyde kullanılan kaba yemlerin, lignin içeriği düşük, NDF parçalanabilirliğinin ise yüksek olması gerekmektedir. Nitekim kaba yemlerin rumen geçiş hızının düşük olmas1, kuru madde tüketimini sınırlandırarak süt verimin düşmesine neden olabilmektedir (Keleş ve Çıbık, 2014). Diğer taraftan kaliteli bir kaba yem de ADF oranının $\quad \% 30$ ve altında, NDF oranının ise $\% 40$ ve altında bir değer olması istenilmektedir (Ateş, 2012). Çalışmada belirlenen en yüksek ADF ve NDF oranı DS 0224 (\% 37.47-60.24), en düşük ise OSSK 596 (\% 28.66-50.53) çeşidinde belirlenmiştir (Tablo 2). Meeske ve ark. (2000)'nın, 21 mısır çeşidi ile yürüttükleri çalışmalarında mısır silajı için tespit ettikleri ADF oranı \% 22.9-26.6, NDF oranı ise \% 43.050.1 arasında değişmiştir.

İki yıllık ortalamalar dikkate alındığında en düşük $\mathrm{P}$ oranı \% 0.251 ile Cadız, en yüksek ise $\quad \%$ 0.290 ile SY Lucrosa çeşitlerinde belirlenmiştir (Tablo 2). Hayvanların $P$ ihtiyaçlarının karşılanması için kaba yemlerde bulunması $\% \quad 0.2$ düzeyinde $\mathrm{P}$ içermesi önerilmektedir (Anon, 1971). Çalışmada tüm işlemlerde belirlenen $\mathrm{P}$ oranları istenen düzeyin üzerinde olmuştur.

Birleştirilmiş yıllara göre silajlık mısır çeşitlerinde $\mathrm{Ca}$ oranı \% 0.254 (Sakarya) - 0.696 (BC 678) arasında değişirken, ortalama ise \% 0.479 olmuştur (Tablo 2). Çalışmada tüm işlemlerde belirlenen $\mathrm{Ca}$ oranları kaba 
yemlerde bulunması gereken değerin (\% 0.3) (Kidambi ve ark., 1989) üzerinde olmuştur. Araştırma sonucunda belirlenen Ca oranı, Özata ve ark, (2012)'nin belirlemiş olduğu bulgular (\% 0.17-0.37) ile uyum içerisindedir.

Tablo 2. Farklı silajlık mısır çeşitlerinde silajlarında ve tanelerinde belirlenen bazı kalite özellikleri (\%)

\begin{tabular}{|c|c|c|c|c|c|c|c|c|c|}
\hline & \multicolumn{3}{|c|}{ Silajda kuru madde oranı } & \multicolumn{3}{|c|}{ Silajda ham protein oranı } & \multicolumn{3}{|c|}{ Silajda ADF oranı } \\
\hline & 2013* & $2014 * *$ & Ort.** & $2013 * *$ & $2014 * *$ & Ort.** & $2013 * *$ & $2014 * *$ & Ort.** \\
\hline 1 & $36.16 \mathrm{a}$ & $33.02 \mathrm{a}$ & $34.58 \mathrm{a}$ & $7.78 \mathrm{ab}$ & $6.90 \mathrm{~d}$ & $7.34 \mathrm{e}$ & $32.30 \mathrm{a}$ & $36.40 \mathrm{c}$ & $34.35 \mathrm{~b}$ \\
\hline 2 & $29.43 \mathrm{bc}$ & $27.31 \mathrm{~d}$ & $28.36 \mathrm{~d}$ & $6.34 \mathrm{c}$ & $8.05 \mathrm{c}$ & $7.20 \mathrm{e}$ & $32.48 \mathrm{a}$ & $37.12 \mathrm{bc}$ & $34.80 \mathrm{~b}$ \\
\hline 3 & $32.96 \mathrm{ab}$ & $32.33 \mathrm{a}$ & $32.64 \mathrm{ab}$ & $7.37 \mathrm{~b}$ & $8.04 \mathrm{c}$ & $7.70 \mathrm{~cd}$ & $32.25 \mathrm{a}$ & $32.90 \mathrm{~d}$ & $32.57 \mathrm{c}$ \\
\hline 4 & $33.65 \mathrm{ab}$ & 29.78 bc & $31.71 \mathrm{abc}$ & $9.37 \mathrm{a}$ & $8.83 \mathrm{~b}$ & $9.09 \mathrm{a}$ & $27.11 \mathrm{c}$ & $38.69 \mathrm{~b}$ & $32.90 \mathrm{c}$ \\
\hline 5 & $26.60 \mathrm{c}$ & $31.13 \mathrm{ab}$ & $28.86 \mathrm{~cd}$ & $8.50 \mathrm{a}$ & $8.31 \mathrm{c}$ & $8.40 \mathrm{~b}$ & $27.52 \mathrm{c}$ & $29.80 \mathrm{e}$ & $28.66 \mathrm{e}$ \\
\hline 6 & $32.52 \mathrm{ab}$ & $28.29 \mathrm{~cd}$ & $30.40 \mathrm{bcd}$ & $6.02 \mathrm{c}$ & $8.27 \mathrm{c}$ & $7.15 \mathrm{e}$ & $34.12 \mathrm{a}$ & $40.66 \mathrm{a}$ & $37.39 \mathrm{a}$ \\
\hline 7 & 29.26 bc & $31.80 \mathrm{ab}$ & $30.53 \mathrm{bcd}$ & $7.54 \mathrm{~b}$ & $6.29 \mathrm{e}$ & $6.92 \mathrm{e}$ & $30.01 \mathrm{~b}$ & $32.65 \mathrm{~d}$ & $31.30 \mathrm{~d}$ \\
\hline 8 & $32.09 \mathrm{ab}$ & $31.41 \mathrm{ab}$ & $31.73 \mathrm{abc}$ & $6.58 \mathrm{c}$ & $9.39 \mathrm{a}$ & $7.98 \mathrm{c}$ & $33.96 \mathrm{a}$ & $40.97 \mathrm{a}$ & $37.47 \mathrm{a}$ \\
\hline 9 & $33.83 \mathrm{ab}$ & $32.94 \mathrm{a}$ & $33.40 \mathrm{ab}$ & $7.93 \mathrm{ab}$ & $9.14 \mathrm{ab}$ & $8.53 \mathrm{~b}$ & $29.27 \mathrm{~b}$ & $35.76 \mathrm{c}$ & $32.51 \mathrm{c}$ \\
\hline Ort & & & 31.36 & & & 7.81 & & & 33.55 \\
\hline \multirow[t]{3}{*}{-} & $31.84 \mathrm{~A} *$ & 30.89 B* & & $7.49 \mathrm{~B} * *$ & $8.14 \mathrm{~A}^{* *}$ & & 31.00 B** & 36.10 A** & \\
\hline & \multicolumn{3}{|c|}{ Silajda NDF oranı } & \multicolumn{3}{|c|}{ Silajda Potasyum (K) oranı } & \multicolumn{3}{|c|}{ Silajda Fosfor (P) oranı } \\
\hline & $2013 * *$ & $2014 * *$ & Ort.** & 2013 & 2014* & Ort. & 2013 & 2014 & Ort. \\
\hline 1 & $53.08 \mathrm{c}$ & $54.82 \mathrm{de}$ & $53.95 \mathrm{e}$ & 1.189 & $1.460 \mathrm{a}$ & 1.324 & 0.243 & 0.261 & 0.251 \\
\hline 2 & $56.92 \mathrm{~b}$ & $55.50 \mathrm{~d}$ & $56.21 \mathrm{c}$ & 1.064 & $1.390 \mathrm{ab}$ & 1.227 & 0.298 & 0.236 & 0.267 \\
\hline 3 & $57.15 \mathrm{~b}$ & $54.90 \mathrm{de}$ & $56.03 \mathrm{c}$ & 1.164 & $1.146 \mathrm{bc}$ & 1.155 & 0.295 & 0.231 & 0.263 \\
\hline 4 & $47.31 \mathrm{e}$ & $58.99 \mathrm{~b}$ & $53.15 \mathrm{~d}$ & 1.103 & $1.202 \mathrm{abc}$ & 1.152 & 0.304 & 0.277 & 0.290 \\
\hline 5 & $50.32 \mathrm{~d}$ & $50.74 \mathrm{~d}$ & $50.53 \mathrm{f}$ & 1.082 & $1.080 \mathrm{c}$ & 1.080 & 0.299 & 0.237 & 0.268 \\
\hline 6 & $58.76 \mathrm{a}$ & $58.37 \mathrm{bc}$ & $58.56 \mathrm{~b}$ & 1.177 & $1.217 \mathrm{abc}$ & 1.197 & 0.282 & 0.247 & 0.264 \\
\hline 7 & $53.38 \mathrm{c}$ & 52.25 ef & $52.81 \mathrm{e}$ & 1.099 & $1.369 \mathrm{abc}$ & 1.234 & 0.305 & 0.245 & 0.275 \\
\hline 8 & $59.01 \mathrm{a}$ & $61.80 \mathrm{a}$ & $60.40 \mathrm{a}$ & 1.282 & $1.512 \mathrm{a}$ & 1.397 & 0.275 & 0.262 & 0.268 \\
\hline 9 & $52.49 \mathrm{c}$ & $56.09 \mathrm{~cd}$ & 54. & 1.126 & $1.488 \mathrm{a}$ & 1.307 & 0.297 & 0.267 & 0.282 \\
\hline Ort & & & & & & 1.231 & & & 0.270 \\
\hline \multirow[t]{3}{*}{. } & 54.27 B ** & $55.94 A^{* *}$ & 55.10 & 1.143 & 1.318 & & 0.288 & 0.251 & \\
\hline & \multicolumn{3}{|c|}{ Silajda Kalsiyum (Ca) oranı } & \multicolumn{3}{|c|}{$\begin{array}{c}\text { Silajda Magnezyum (Mg) } \\
\text { oranı }\end{array}$} & \multicolumn{3}{|c|}{ Tanede ham protein oranı } \\
\hline & 2013 & $2014 * *$ & Ort.** & $2013 * *$ & $2014 * *$ & Ort.** & $2013 * *$ & $2014 * *$ & Ort.** \\
\hline 1 & 0.555 & 0.6 & $0.603 \mathrm{a}$ & $0.301 \mathrm{a}$ & $0.337 \mathrm{a}$ & $0.319 \mathrm{a}$ & $6.55 \mathrm{~cd}$ & $7.63 \mathrm{bc}$ & $7.09 \mathrm{~cd}$ \\
\hline 2 & 0.510 & $0.625 \mathrm{~b}$ & $0567 \mathrm{ab}$ & $0.189 \mathrm{~b}$ & $0.334 \mathrm{a}$ & $0.262 \mathrm{~b}$ & $6.08 \mathrm{~d}$ & $6.71 \mathrm{c}$ & $6.40 \mathrm{~d}$ \\
\hline 3 & 0.233 & $0.276 \mathrm{~d}$ & $0.254 \mathrm{~d}$ & $0.169 \mathrm{~b}$ & $0.268 \mathrm{c}$ & $0.218 \mathrm{~d}$ & $7.69 \mathrm{bcd}$ & $8.22 \mathrm{bc}$ & $7.96 \mathrm{bc}$ \\
\hline 4 & 0.355 & $0.418 \mathrm{~cd}$ & $0.387 \mathrm{~cd}$ & $0.174 \mathrm{~b}$ & $0.252 \mathrm{c}$ & $0.213 \mathrm{~d}$ & $8.70 \mathrm{~b}$ & $7.79 \mathrm{bc}$ & $8.24 \mathrm{~b}$ \\
\hline 5 & 0.404 & $0.483 \mathrm{bc}$ & $0.443 \mathrm{bc}$ & $0.203 \mathrm{~b}$ & $0.302 \mathrm{ab}$ & $0.252 b c$ & $7.53 \mathrm{bcd}$ & $8.31 \mathrm{bc}$ & $7.92 \mathrm{bc}$ \\
\hline 6 & 0.557 & & $0.608 \mathrm{a}$ & $0.224 \mathrm{~b}$ & $0.321 \mathrm{a}$ & & $10.83 \mathrm{a}$ & $11.89 \mathrm{a}$ & $11.36 \mathrm{a}$ \\
\hline 7 & 0.548 & $3 \mathrm{a}$ & $0.696 \mathrm{a}$ & $0.201 \mathrm{~b}$ & $0.306 \mathrm{ab}$ & $0.253 \mathrm{bc}$ & $8.22 \mathrm{bc}$ & $8.69 \mathrm{~b}$ & $8.46 \mathrm{~b}$ \\
\hline 8 & 0.309 & $0.335 \mathrm{~cd}$ & $0.322 \mathrm{~cd}$ & $0.222 \mathrm{~b}$ & $0.319 \mathrm{a}$ & $0.270 \mathrm{~b}$ & $8.23 \mathrm{bc}$ & $8.37 \mathrm{bc}$ & $8.30 \mathrm{~b}$ \\
\hline 9 & 0.373 & $0.484 \mathrm{bc}$ & $0.428 \mathrm{bc}$ & $0.227 \mathrm{~b}$ & $0.280 \mathrm{bc}$ & $0.253 \mathrm{bc}$ & 7.44 bcd & $7.98 \mathrm{bc}$ & $7.71 \mathrm{c}$ \\
\hline Or & & & 0.479 & & & 0.257 & & & 8.16 \\
\hline \multirow[t]{3}{*}{$\cdot$} & $27 \mathrm{~B} *$ & $0.530 A^{*}$ & & 212 B* & $0.302 A^{*}$ & & $7.92 \mathrm{~B} * *$ & $8.40 \mathrm{~A}^{* *}$ & \\
\hline & \multicolumn{3}{|c|}{ Tanede nişasta oranı } & \multicolumn{3}{|c|}{ Tanede yă̆ oranı } & \multicolumn{3}{|c|}{ Tanede ham kül oranı } \\
\hline & $2013 * *$ & $2014 * *$ & Ort.** & 2013* & $2014 * *$ & Ort.* & $2013 * *$ & $2014 * *$ & Ort.** \\
\hline 1 & $68.03 \mathrm{a}$ & $66.86 \mathrm{c}$ & $67.45 \mathrm{ab}$ & $4.90 \mathrm{abc}$ & $4.24 \mathrm{c}$ & $4.57 \mathrm{~cd}$ & $2.18 \mathrm{bc}$ & $2.11 \mathrm{~d}$ & $2.14 \mathrm{~cd}$ \\
\hline 2 & $69.65 \mathrm{a}$ & $64.20 \mathrm{~d}$ & $66.93 \mathrm{ab}$ & $5.20 \mathrm{a}$ & $4.95 \mathrm{ab}$ & $5.07 \mathrm{ab}$ & $2.06 \mathrm{c}$ & $2.43 \mathrm{a}$ & $2.24 \mathrm{bc}$ \\
\hline 3 & $65.90 \mathrm{ab}$ & $63.87 \mathrm{~d}$ & $64.88 \mathrm{c}$ & $5.12 \mathrm{a}$ & $4.92 \mathrm{ab}$ & $5.02 \mathrm{abc}$ & $2.26 \mathrm{bc}$ & $2.25 \mathrm{~b}$ & $2.26 \mathrm{bc}$ \\
\hline 4 & $63.96 \mathrm{~b}$ & $68.31 \mathrm{ab}$ & 66.14 bc & $4.46 \mathrm{bc}$ & $4.71 \mathrm{~b}$ & $4.58 \mathrm{~cd}$ & $2.43 \mathrm{ab}$ & $2.18 \mathrm{c}$ & $2.30 \mathrm{~b}$ \\
\hline 5 & $67.79 \mathrm{a}$ & $64.84 \mathrm{~d}$ & $66.31 \mathrm{bc}$ & $5.11 \mathrm{ab}$ & $5.54 \mathrm{a}$ & $5.32 \mathrm{a}$ & $2.19 \mathrm{bc}$ & $2.27 \mathrm{~b}$ & $2.23 \mathrm{bcd}$ \\
\hline 6 & $59.16 \mathrm{c}$ & $62.61 \mathrm{e}$ & $60.88 \mathrm{~d}$ & $4.31 \mathrm{c}$ & $5.33 \mathrm{a}$ & $4.81 \mathrm{bcd}$ & $2.62 \mathrm{a}$ & $2.40 \mathrm{a}$ & $2.51 \mathrm{a}$ \\
\hline 7 & $66.74 \mathrm{ab}$ & $64.97 \mathrm{~d}$ & $65.85 \mathrm{bc}$ & $4.93 \mathrm{abc}$ & $5.10 \mathrm{ab}$ & $5.01 \mathrm{abc}$ & $2.18 \mathrm{bc}$ & $2.26 \mathrm{~b}$ & $2.22 \mathrm{bcd}$ \\
\hline 8 & $66.42 \mathrm{ab}$ & $68.06 \mathrm{~b}$ & $67.24 \mathrm{ab}$ & $4.65 \mathrm{abc}$ & $4.88 \mathrm{ab}$ & $4.77 \mathrm{abc}$ & $2.30 \mathrm{bc}$ & $2.04 \mathrm{e}$ & $2.17 \mathrm{~cd}$ \\
\hline 9 & $68.14 \mathrm{a}$ & $69.28 \mathrm{a}$ & $68.71 \mathrm{a}$ & $4.31 \mathrm{c}$ & $4.66 \mathrm{bc}$ & $4.48 \mathrm{~d}$ & $2.20 \mathrm{bc}$ & $2.01 \mathrm{e}$ & $2.10 \mathrm{~d}$ \\
\hline Ort & & & 66.04 & & & 4.85 & & & 2.24 \\
\hline . & 66.20 & 65.89 & & 4.78 B* & $4.93 A^{*}$ & & $2.27 \mathrm{~A}^{*}$ & 2.22 B* & \\
\hline
\end{tabular}


(*: p<0.05, **: p<0.01). 1: Cadız, 2: Colonia, 3: Sakarya, 4: SY Lucrosa, 5: OSSK 596, 6: Arifiye, 7: BC 678, 8: DS 0224, 9: Truva.

Tanede belirlenen en yüksek ham protein oranı \% 11.36 ile Arifiye, en düșük ise \% 6.40 ile Colonia çeşitlerinde belirlenmiştir (Tablo 2). Tanedeki proteinin \% 75'i, nişastanın ise \% 98'i endospermde oluşmaktadır. Bu yüzden misır tanesinde nişasta oranı ile protein oranı ters orantılidır (Feil, 1997; Kırtok, 1998; Acuna ve ark., 2005). Çalışmada farklı misır çeşitlerinde artan nişasta oranına bağlı olarak protein oranlarının düşmesi bu bulguyu doğrulamaktadır (Tablo 2).

Mısır silajının içermiș olduğu enerji değerinin yaklaşık yarısı nişastadan kaynaklanmaktadır (Hill, 1993). Dolayısıyla mısır silajının içermiş olduğu nişasta miktarının yüksek olması, yemin kullanılabilirliğini artırırken, yem maliyetini düşürmekte ve hayvan performansını da arttırmaktadır (Keleş ve Çıbık 2015). Mısırın nişasta içeriği silajın besleme değeri yanında silolama kolaylığı açısından da önemlidir. Silajlık mısırda nişasta kaynağı olarak tane büyük bir paya sahiptir. Tanenin nişasta oranı olum dönemine bağlı olarak değişim göstermekte ve en yüksek değerine hamur olum döneminde ulaşmaktadır (Hill, 1993; Kantarcı ve ark., 2016). Ayrıca tanenin kimyasal içeriği genetik faktörlere de bağlı olarak da değişebilmekte ve bu nedenle de misır çeşitlerinin silaj verimleri ve kaliteleri farklılık gösterebilmektedir. Çalıșmada silajlık mısır tanesinde belirlenen en düşük nişasta oranı \% 60.88 ile Arifiye, en yüksek ise Truva (\% 68.71), Cadız (\% 67.45), DS 0224 (\% 67.24) ve Colonia (\% 66.24) çeşitlerinden elde edilmiştir (Tablo 2). Yıldırım (2004), Çukurova bölgesinde farklı mısır çeşitleriyle yapmış olduğu çalışmada nişasta oranını \% 75-85 arasında değiştiğini bildirilmiştir.
Birleştirilmiş yıllara göre yapılan korelasyon analizine göre incelenen özellikler arasındaki ilișkiler ve önemlilik dereceleri Tablo 3'de görülmektedir. Buna göre incelenen özellikler arasında en güçlü ilişsi tanedeki nişasta ve kül oranı arasında $(\mathrm{r}=-0.950)$ belirlenmiştir. Tanenin nişasta ve protein oranı arasında çok önemli ve negatif $(r=-0.846)$ bir ilişki tespit edilmiştir. Buna göre tanede nişasta oranının artması ile protein oranının düştüğü görülmektedir. Tanede nişasta ve proteinin sentezi olum dönemi ile yakından ilişkili olup erken dönemde protein geç dönemde ise nişasta daha yoğun sentezlenmektedir. Silajın $\mathrm{Mg}$ içeriği; P ve ham protein içeriği ile güçlü ve olumsuz (sırasıyla $r=$ -0.514 ve $\mathrm{r}=-0.680), \mathrm{K}$ ve $\mathrm{Ca}$ ile olumlu ( $\mathrm{r}=$ 0.589 ve $r=0.555)$ korelasyon göstermiştir.

Tane ve silaj özellikleri arasındaki ilişki ele alındığında ise; silajın protein oranı ilginç bir şekilde tanenin nişasta oranı ile olumlu $(r=0.375)$, protein oranı ile olumsuz $(\mathrm{r}=-0.137)$ bir ilişki göstermiştir (Tablo 3). Tanenin nişasta oranının yükselmesi bitkinin olgunluğuna işaret etmektedir. Dolayısıyla tanenin yüksek nişasta içerdiği dönemde bitkinin protein oranının da düşük olması beklenir. Ancak, belirlenen ilişki bunun tersi bir sonuç ortaya koymuştur. $\mathrm{Bu}$ durum ele alınan çeşitler arsındaki genetik farklılıktan ve vejetatif kısımların protein içeriğine bağlı olarak ortaya çıkmış olabilir. Bunun yanında, nişastanın fermantasyon için önemli olması nedeniyle, bu ilişki silaj kalitesi adına oldukça önemli ve ümit vericidir. Silaj ve tane arasında en yüksek ilişki silajın kuru madde oranı ile tanenin yă̆ oranı arasında $(\mathrm{r}=0.758)$ belirlenmiştir. Tanenin yağ oranı ile silajın K oranı arasında da olumsuz bir ilişki ( $\mathrm{r}$ $=-0.695$ ) bulunmaktadir (Tablo 3).

Tablo 3. Korelasyon analizine göre incelenen özellikler arasındaki ilişkiler ve önemlilik dereceleri

\begin{tabular}{llllllllllll}
\hline & SPR & SADF & SNDF & SK & SP & SCa & SMg & TPR & TNIŞ & TYA Ğ & TKÜL \\
\hline SKM & 0.171 & 0.155 & 0.044 & 0.507 & -0.108 & -0.232 & 0.233 & -0.090 & 0.299 & $0.758^{* *}$ & 0.414 \\
SPR & & -0.323 & -0.315 & -0.205 & $0.668^{*}$ & -0.649 & -0.514 & -0.137 & 0.375 & -0.306 & -0.206 \\
SADF & & & $0.921^{* *}$ & 0.613 & -0.256 & 0.035 & 0.387 & 0.355 & -0.309 & -0.511 & 0.319 \\
SNDF & & & & 0.556 & -0.250 & -0.193 & 0.193 & 0.315 & -0.291 & -0.326 & 0.261 \\
SK & & & & & -0.172 & 0.064 & 0.589 & -0.155 & 0.425 & $-0.695^{*}$ & -0.495 \\
SP & & & & & & -0.217 & $-0.680^{*}$ & 0.039 & 0.210 & -0.240 & -0.017 \\
SCa & & & & & & & 0.555 & 0.147 & 0.204 & 0.135 & 0.182 \\
SMg & & & & & & & & -0.046 & 0.104 & -0.236 & -0.208 \\
TPR & & & & & & & & & $-0.846^{* *}$ & -0.060 & $0.787^{*}$ \\
TNiŞ & & & & & & & & & & -0.282 & $-0.950^{* *}$ \\
TYAG & & & & & & & & & & & 0.243 \\
\hline
\end{tabular}

$\left(*: \mathrm{p}<0.05 .{ }^{* *}: \mathrm{p}<0.01\right)$. SKM: silajın kuru maddesi; SPR: silajın protein oranı; SADF: silajın ADF oranı; SNDF: silajın NDF oranı; SK: silajın K oranı; SP: silajın P oranı; SCa: silajın Ca oranı; SMg: silajın Mg oranı; TPR: tanede protein oranı, TNIŞ: tanede nişasta oranı; TYAĞ: tanede yă̆ oranı; TKÜL: tanede kül oranı.

İki yıllık ortalama sonuçlara göre, misır çeşitleri arasında silaj kalitesi bakımından Cadız, SY Lucrosa ve Truva çeşitlerinin öne çıktığı görülmektedir. Bu çeşitlerin hepsi geçcidir. Dolayısıyla (kalite özellikleri açısından) bölgemizde ana ürün olarak silajlık misır yetiştiriciliğinde geçci çeşitlerin seçilmesi uygun olabilir.

\section{KAYNAKLAR}

Acuna ML, Savin R, Curá JA, Slafer GA 2005. Grain protein quality in response to changes in preanthesis duration in wheats released in 1940, 1964 and 1994. J. Agron. Crop Sci. 191: 226-232. 
Alçiçek A, Kılıç A. Ayhan V, Özdoğan M 2010. Türkiye'de kaba yem üretimi ve sorunları. Türkiye Ziraat Mühendisliği VII. Teknik Kongresi, 11-15 Ocak, Ankara.

Arslan N, Erdurmuş C, Öten M, Aydınoğlu B, Çakmakçı S 2016. Mısır ile soyanın farklı oranlarda karıştırılmasıyla elde edilen silajlarda besin değerinin belirlenmesi. Anadolu Tarım Bilimleri Dergisi, 31.

Arslan N, Erdurmuş C, Öten M, Aydınoğlu B, Çakmakçı S 2017. Misır (Zea mays L.) ile Leucaena leucocephala L. Bitkisinin Karıştırılmasıyla Hazırlanan Silajların Besin Değerinin Belirlenmesi. Ege Üniv. Ziraat Fak. Dergisi, 54(1):101-106

Deniz S, Nursoy H, Yımaz İ, Karslı MA 2001. Vejetasyonun farklı devrelerinde hasat edilmenin bazı misır varyetelerinde besin madde içeriği ve silaj kalitesi ile sindirilebilir kuru madde miktarına etkisi. Veteriner Bilimleri Dergisi, 17(3): 43-49.

Feil B 1997. The inverse yield-protein relationship in cereals, possibilities and limitations for genetically improving the grain protein yield. Trends Agron.1:103-119.

Hill JH 1993. How a Corn Plant Develops. Special Reports No:48, Iowa State University of Science and Techonology Cooperative Extension Service, Ames, Iowa.

Keleş G, Çıbık, M 2014. Mısır silajının besin ve besleme değerini etkileyen faktörler. Hayvansal Üretim 55(2): 27-37.

Kantarcı D, Pazır F, İştipliler D, Tosun M, Tonk, FA 2016. Tatlı Misırın Kalite Kriterlerine Göre Optimum Hasat Zamanının Belirlenmesi. Tarla
Bitkileri Merkez Araştırma Enstitüsü Dergisi, 25 (Özel say1-1):70-73

Kaya Ö, Polat C 2010. Tekirdağ İli Koşullarında I. ve II. Ürün Olarak Yetiştirilen Bazı Mısır Çeşitlerinin Silaj Fermantasyon Özellikleri ve Yem Değerinin Belirlenmesi. Journal of Tekirdag Agricultural Faculty, 7(3): 129-136.

Kırtok Y 1998. Mısır Üretimi ve Kullanımı, Nişasta ve Glikoz Üreticileri Derneği Yayınları, Ankara.

Kidambi SP, Matches AG and Gricgs TC 1989. Variability for $\mathrm{Ca}, \mathrm{Mg}, \mathrm{K}, \mathrm{Cu}, \mathrm{Zn}$, and $\mathrm{K} /(\mathrm{Ca}+\mathrm{Mg})$ ratio among 3 wheat grasses and sainfoin on the southern high plains. Journal of Range Management, 42: 316-322.

Kün E 1985. Sıcak İklim Tahılları. A.Ü. Ziraat Fakültesi Yayınları 953, Ankara Üniversitesi Basımevi, Ankara 317.

Meeske R, Basson HM, Pienaa JP and Cruywagen CW 2000. A comparison of the yield, nutritonal value and predicted production potentiel of different maize hybrids for silage production. South African Journal of Animal Science, 30(1):18-21.

Özata E, Öz A, Kapar H 2012. Silajlık hibrit mısır çeşit adaylarının verim ve kalite özelliklerinin belirlenmesi. Tarım Bilimleri Araştırma Dergisi, 5(1): 37-41.

Yaylak E, Alçiçek A 2003. Sığır besiciliğinde ucuz bir kaba yem kaynağı: Misır Silajı. Hayvansal Üretim Dergisi 44 (2), 29-36.

Yıldırım A 2004. Çukurova Bölgesinde Farklı Lokasyonlarında Yetiştirilen Sekiz Mısır (Zea mays L.) Çeşidinin Verim Ve Kalite Unsurlarının Belirlenmesi Üzerinde Bir Araştırma. Çukurova Üniversitesi Fen Bilimleri Enstitüsü, Tarla Bitkileri ABD, Doktora Tezi. 